DOI: $10.2478 /$ ace-2013-0029

\title{
RESEARCH ON THE PORTUGUESE BUILDING STOCK AND ITS IMPACTS ON ENERGY CONSUMPTION - AN AVERAGE U-VALUE APPROACH
}

\author{
J. SOUSA ${ }^{1}$, L. BRAGANÇA ${ }^{2}$, M. ALMEIDA ${ }^{3}$, P. SILVA ${ }^{4}$
}

\begin{abstract}
The article aims to evaluate the Portuguese building stock energy policies and strategy for energy saving in buildings among the EU members. It was found out the average heat transfer coefficients of the main structural elements of Portuguese Buildings and analyzed the U-values of this elements considering different time periods.

The fundamentals of this study were funded by the Agency for Development and Innovation (ADI) and co-financed by the European Regional Development Fund (FEDER) through the Operational Program for Competitiveness Factors (POFC) assigned to the Building Physics and Construction Technology Laboratory with the reference SB Tool SPT_2011_4.
\end{abstract}

Keywords: Building Stock; Energy Resources; Energy Consumption; Building Structural Elements; Average Heat Transfer Coefficient.

\section{INTRODUCTION}

There is a generalized awareness of world population that the evolution and progression of our planning is based in an unsustainable development. Nowadays households continue increasing $\mathrm{CO}_{2}$ production [1].

Forty decades later after the first oil crisis there is a growing concerning about energy efficiency in the housing sector [2]. These preoccupations are motivated by several concerns related with global warming, fossil fuel dependence and environmental issues. It is estimated that one-fifth of total global energy demand originates from requirements of users in the residential sector for heating, cooling, and lighting of residential dwellings [3]. In Portugal, as well as in many European Countries, the 1970's oil crisis led to a significant change not only in the standards of energy consumption in residential buildings, but also in the construction techniques used in residential buildings, which have been becoming more accurate with time.

1 Faculty of Engineering, University of Porto, Portugal. E-mail: j.bastos.sousa@gmail.com Address: Rua do Neiva, 274200 Porto, (Corresponding author).

2,3,4 Civil Engineering Department, University of Minho: braganca@civil.uminho.pt; malmeida@civil.uminho.pt; psilva@civil.uminho.pt. 
"In the building sector, one of the main challenges is the higher thermal comfort requirements of the general population, which has led to an increase in the heating and cooling energy consumption" [4]. With the increase of purchasing power, peoples' comfort standards have changed, once they began to consider that these comfort levels are the necessary to realize basic values and become fundamental to purchase [5]. This caused an inefficient heating control due to the lack of know-how from the users. Actually, it is estimated that about $40 \%$ of the energy consumption provided in Europe is consumed in buildings and it is expected that this growth trend in energy consumption will remain until 2050 [6]. The excessive and unsustainable energy consumptions can have a real impact in the environment. The construction industry sector in Portugal represents about $30 \%$ of the impact on the environment [7]. The energy consumption can be reduced in more than $50 \%$, though the adoption of efficiency measures that can represent till 400 million tones of reduced $\mathrm{CO}_{2}$ for year, in Europe [8].

Present demands on energy will continue even if all the buildings, built in the future, have very low energy consumes. This only would reduce the energy demand increase.

This means that, only measures considering already existing buildings will have effect on the total energy demands in the European building stock, what is reflected in the European energy policy orientation as the energy performance of building directive (EPBD) 2002/91/EC and its recast (EPBD) 2010/31/EU indicates, in what regards to the conservation and efficient use of energy in buildings [9].

It been has shown [10] that if all retrofit measures covered by the EPBD were realized in all the European building stock, at the same time, including multi-family houses, non-residential buildings and all single-family houses, the amount of $\mathrm{CO}_{2}$ emission savings could reach to $398 \mathrm{Mt} / \mathrm{a}$; a reduction about $60 \%$ in a building stock that accounts $678 \mathrm{Mt} / \mathrm{a}$ for $\mathrm{CO}_{2}$ emissions [11].

Measures related with the retrofitting of building envelope, i.e. insulation improvements of external walls, windows, floors and roof structures should be, primarily, deal with energy-saving when renovating residential buildings as well as measures to reduce the loss of heat through ventilation.

Furthermore, the impact of the politic options that have been taken during the years, are still not reflected in European economy. "Policies about the energy efficiency of dwellings would be redundant if the private market for real capital investment in energy efficiency functioned well enough." [3]. In this context even that correct energy policies in the housing sector are adopted, the real effects would not be seen if the energy market does not work properly.

Due to the increasing in oil and gas prices, it is expected the rise of household energy bills, which will potentiate the energy efficiency market [3].

Through the providing of information to consumers on their energy consumptions, it was shown that energy bills can be substantially reduced [12]. The implementation of energy certificates may improve the awareness of consumers' to energy consumption and reveal the real situation of energy consumption in households. 
The advantages that efficient systems could bring are generally more expensive in what concerns to initial investment. When compared the investment of a direct electric $\mathrm{SH}$ with the investment of a domestic heat pump, the first solution is cheaper than the second, but it consumes more electricity which makes it a more expensive solution with time. The heat pump, although being a solution with higher initial investment, is a more efficient system in a long-term. This is also true for other heating systems i.e. biomass boilers and solar thermal panels [13].

Since a significant part of the Portuguese housing stock is outdated, the implementation of the new European Directive 2010/31/EU emerges as an opportunity to rehabilitate the building stock, turning it more efficient and sustainable.

In 2010, the Portuguese residential sector was the third largest energy consumer, presenting energy consumptions of $18 \%$ of the total energy consumption in the country [14]. Forecasts indicate an upward trend in energy consumption in the housing sector, due to the increasing introduction of air conditioning systems and electrical equipment that are designed to provide greater comfort and life quality for people.

Initially, firewood was the main energy source used both for the daily domestic activities but also for heating the main compartment of dwellings. With the development of comfort requirements, electricity became the most common source of energy in the Portuguese residential stock [14].

The electricity liberalization process has caused significant changes in the European markets. "Electricity is now considered a commodity traded on markets that facilitate trading in short-term and long-term delivery contracts" [15]. In the residential European sector, the average of electricity consumption per capita is very diverse, depending mainly on the level of diffusion of electrical appliances and of the use of electric space heating. The average consumes can range from $1000 \mathrm{kWh} / \mathrm{cap}$ (i.e., Portugal, Italy) to up $4500 \mathrm{kWh} / \mathrm{cap}$ in Sweden. "Southern European countries may be considered as fuel-poor, which is a classic qualitative definition of fuel poverty, with an alarming $45 \%$ of households in Greece, $55 \%$ in Spain and 74\% in Portugal declare this inability." [16].

In 2003, the European Union (EU-15) energy consumptions were about $34,1 \%$ of the worlds' nuclear power, $17,6 \%$ of oil, $15,6 \%$ of natural gas, $11,5 \%$ of hydroelectricity and $8,6 \%$ of coal and it is estimated that, the importation dependency will reach two-thirds of the total European energy consumption by 2020 [17].

The excessive dependence on fossil fuels in countries that are importers of energy has been recognized as a threat in Kyoto protocol [18-20]. In this matter, Portugal is one of the threatened countries. Currently, the GHG emission reduction targets that have been negotiated with the European Union failed, and the importation of energy resources is about $83 \%$ of the country needs $[21,22]$. This scenario originated a bounce back in the country energy politics, diversifying the energy sources that led to a shift in its electricity production system by introducing natural power gas plans, new hydroelectric power plans and wind energy. "Electricity production from natural gas has increased from zero to 12,3 TWh between 1996 and 2006 and has become a significant 
part of the total yearly electricity consumption of $46,9 \mathrm{TWh}$. The total installed capacity for production from all types of renewable energy sources has doubled from 1995 to 2009 and has reached 9,2 GW, by March 2010." [23] The country energetic politic goals pretend the reduction of energy dependence to $74 \%$ and to increase the share of renewable energy sources in final energy consumption to $31 \%$ by 2020 [24].

Southern European countries have the less energy use, per person, for household; according to the International Energy Agency, range from $3370 \mathrm{kWh} /$ person in Portugal, $3600 \mathrm{kWh} /$ person in Spain and reach 11,400 kWh/ person in Finland and 17,700 kWh/ person in Luxembourg. The European reality is comparable with $10,350 \mathrm{kWh} /$ person in USA, where residential building energy use represents about $20 \%$ of total energy consumption and 11,160 kWh/person in Canada $[16,25]$. However, besides Portugal has a small consumption, when compared with other countries, the electrical energy consumption has the trend to keep growing [14].

Since the majority of the Portuguese building stock was built in a time with inexistent thermal regulation, these buildings tend to consume more energy than necessary. The thermal inefficiency of the construction in the Portuguese Building Stock has negative consequences, not only for the dwellers but also for the country economy.

The present study seeks to report the energy reality and consumptions of the Portuguese building stock in the European context and aims to evaluate the evolution on several structural elements from the building with base on the average heat transfer coefficients of exterior walls, roofs and pavements. The average values of these elements were based on the data obtained from the Portuguese Agency for Energy.

\section{Results ANd Discussion}

\subsection{The Portuguese Residential Building Stock}

According to the last known results of 2011 Census, the Portuguese building stock is divided into two categories or statistical units, namely, buildings and lodging (Figure 1) [26]. The main difference between these two concepts is that the first correspond to an independent construction that comprehends one or more lodgings, divisions or other spaces which are destined for housing, independently, if its first goal is commercial, industrial, cultural, residential or other. The second correspond to a place distinct and independent that, by the way it was constructed, reconstructed, amplified or transformed is intended to be a human habitation. Actually is estimated that in Portugal exist 3.544.389 buildings and 5.878.756 lodging, from which 5.859.540 are classic ones [27].

In the Portuguese building stock it is possible to subdivide the housing into collective lodging or family lodging. The first mentioned shall be understood as buildings that were designed or constructed for housing several families (including 
hotels, cohabitation or similar) while the second mentioned, refers to buildings that were designed or constructed to accommodate one single family.
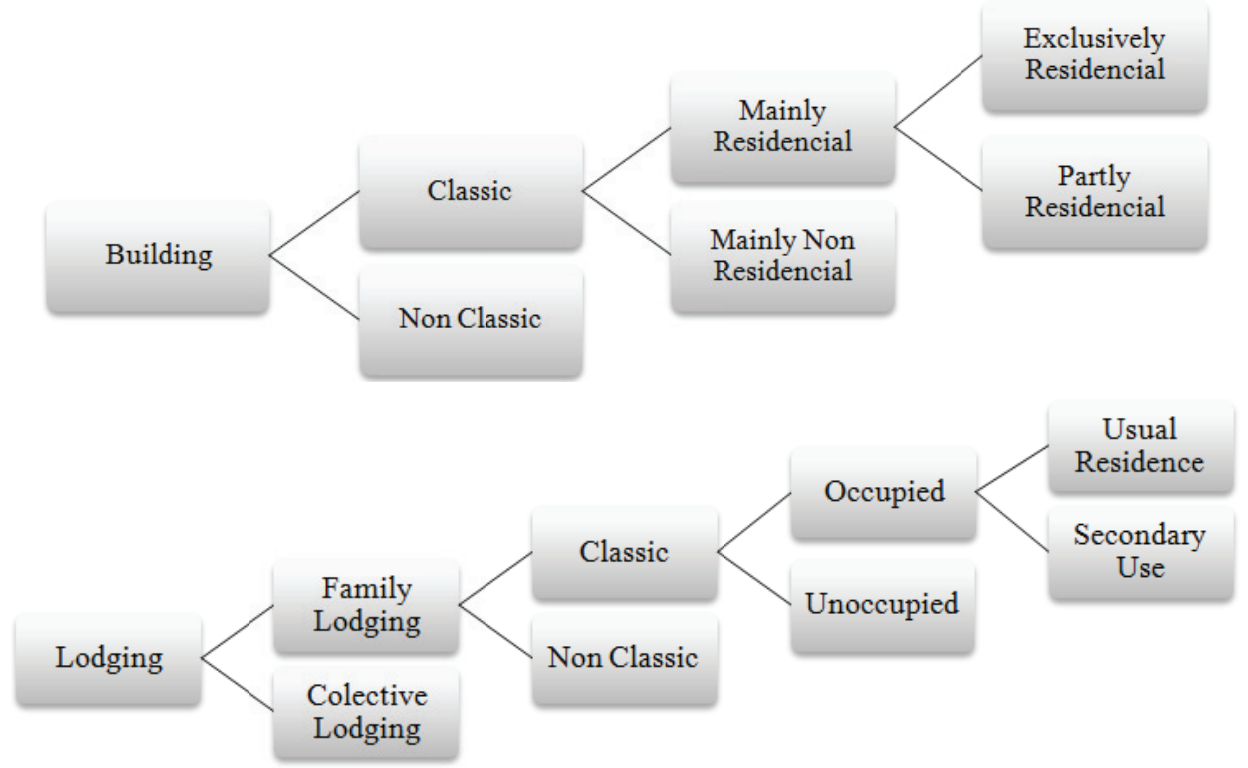

Fig. 1. Characterization of the Statistical Unit Lodging and Building

The percentage of collective accommodation in the Portuguese building stock was almost negligible, representing only $0,21 \%$. Almost the entire national territory $(99,78 \%)$ correspond to a single family housing (including classical and non classical housing).

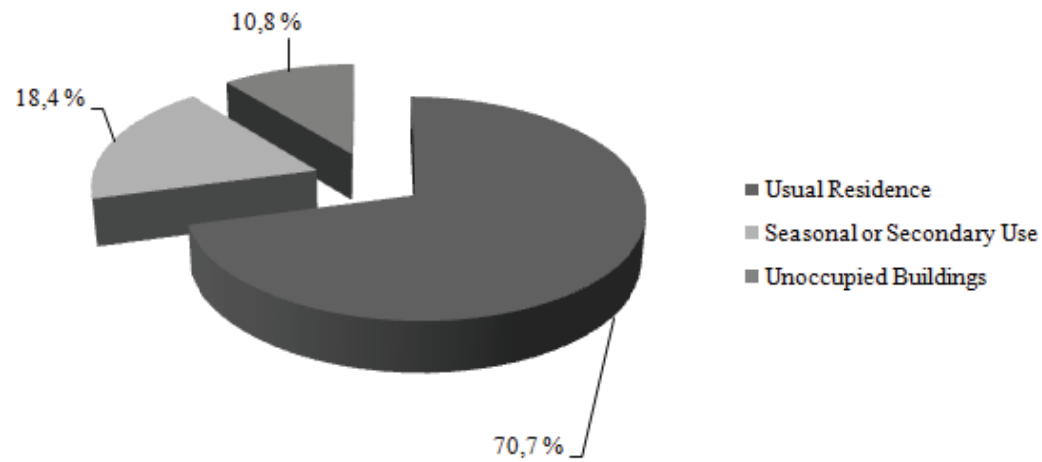

Fig. 2. Percentage of Residence Buildings According with their sate of Occupation 
The significant majority of housing in Portugal (about 99,67\%) correspond to classic family lodging, which means a lodging with a room or a suite of rooms and its attachments that by the way it was built, rebuilt or converted is intended to be the permanent home of a family. The non-classic family lodging includes various groups like accommodation, tents, rudimentary wooden houses, makeshift, mobile or other (locals non intervened by human hand) and represents only about $0,11 \%$ of the Portuguese building stock.

The great majority of buildings in Portugal are used as an ordinary residence (about $68,10 \%$ ), more than in the generality of Europeans Countries, where about $50 \%$ of buildings are occupied by the owner.

Great part of the Portuguese building stock were mainly built during the 1960's, 1970 's and 1980's decades accompanying the country economical growth. According to the data relative of the last known results of the 2011 Census, the majority of the residential buildings in Portugal were built in the mentioned decades, representing about $51 \%$ of all the Portuguese Building Stock (Figure 3). It was found that about $81 \%$ of the buildings were built before 1990 , showing an average age of 33,92 years in 2001 [28].

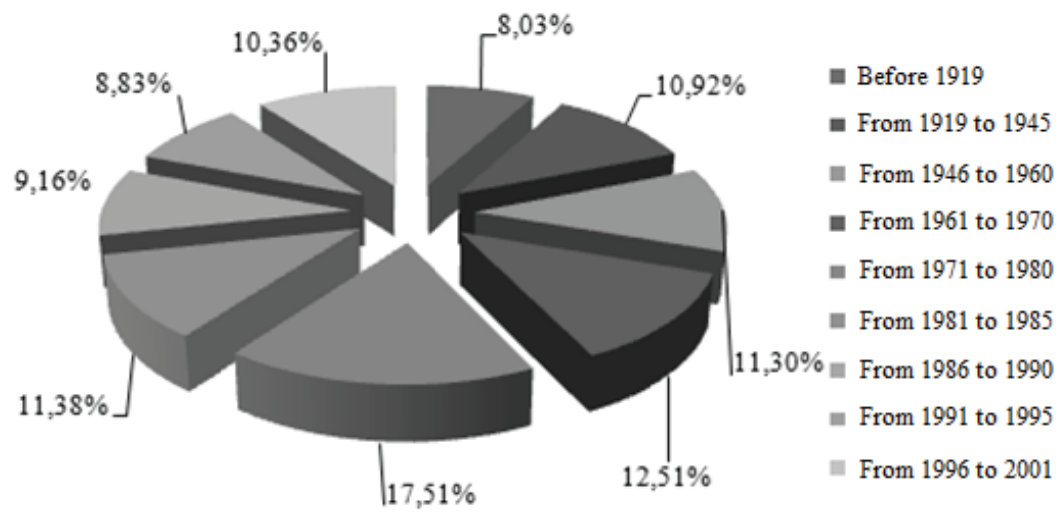

Fig. 3. Percentage of Residential Buildings Divided for Time Period

While in Portugal the residential stock has an average 33 years old, in Europe great part of the stock is older than 50 years and is still in use today [29].

As it is possible to see, in Figure 4, more than $40 \%$ of European residential buildings have been constructed before the 1960's, when the existing energy regulations about buildings were limited or inexistent, like it happened in Portugal.

The North and Central Europe countries, like the United Kingdom (U.K.), Denmark, Sweden, France or Czech Republic are some of the countries with the biggest percentage of older buildings in their building stock. 
In Portugal, as well as in many South European Countries, the largest boom in construction happened between 1960 and 1990. During this same period these growth tendency was also felt with great intensity in the Central and East European Countries but not so much in the North and West Europeans Countries where the main period of construction was before 1960 .

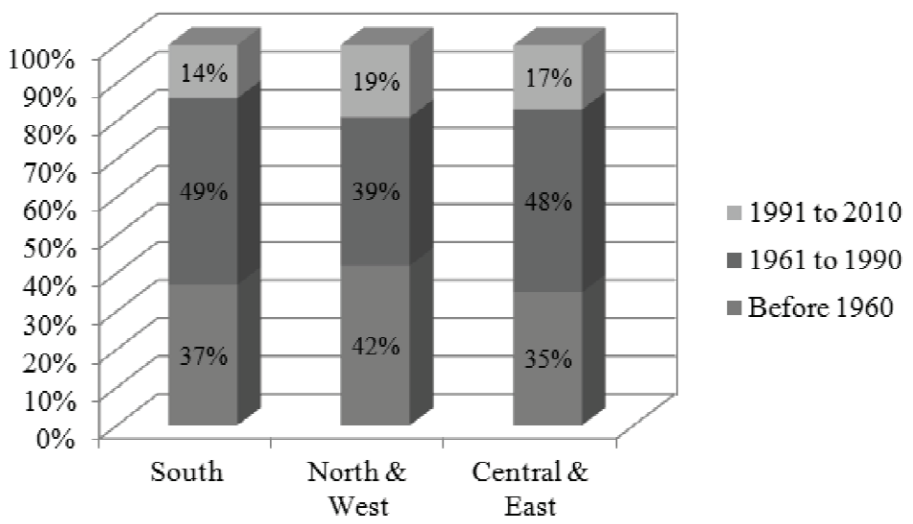

Fig. 4. Percentage of Residential Buildings Divided for Time Period in Europe [6]

The energy performance of buildings depends on various factors such as the construction techniques used in the building envelope, the local climatic conditions, the behaviour of the users, the local ground characteristics, the social conditions as state incentives and regulations, among others. The age of the building is certainly a factor which directly affects the heating consumption levels of the building once that, the older the building is, larger is the probability of spending more energy.

Despite the majority of the Portuguese building stock being relatively recent, great part of this stock is already with repair needs. Those buildings built during 1960's, 1970's and 1980's are the ones with biggest energy saving potential. The lack of thermal regulation is one reason for the thermal inefficiency of the building stock as well as the lack of insulation on the buildings envelope.

\subsection{Intervention and Rehabilitation Needs - Portugal vs Europe}

As mentioned before, during the last decades, Portugal experienced a period of expansion of the building stock which had as consequence an almost total absence of investment in rehabilitation and conservation of the already existing building stock (Figure 5).

The past strong investment in new constructions, the freezing of rents prior to 1990 and, lately, the reduction in the loans to private investors granted by the banks due to the economical crisis are the most significant features that lead to the current poor state 
of repair of a significant part of the Portuguese building stock. Before 1991, there was in force any kind of regulation to impose criteria regarding the thermal behaviour of residential or office buildings. For this reason most of the buildings constructed before the introduction of the first rules of thermal performance of buildings need energy rehabilitation today.

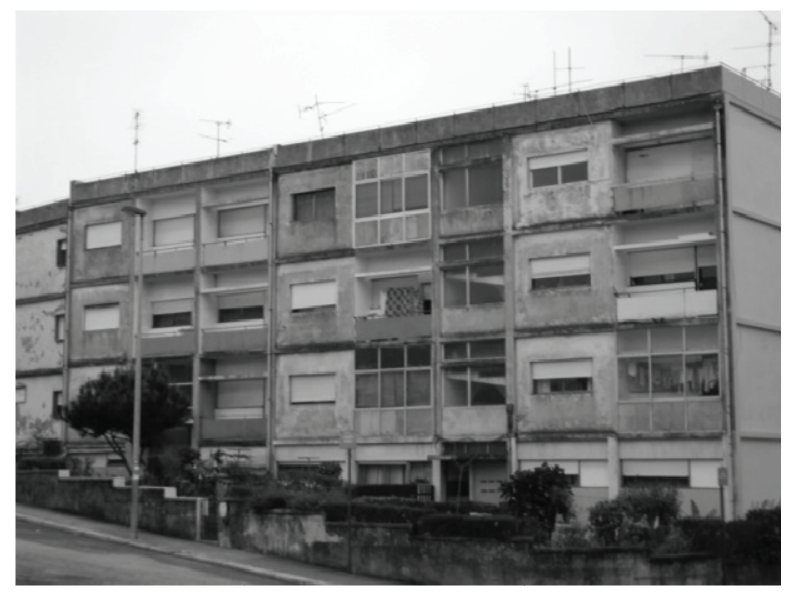

Fig. 5. Portuguese Building Needing Exterior Walls and Window Frames Rehabilitation

The favourable taxes conditions conceded during many years by the Portuguese banks to private investors led many families to home ownership which resulted in an almost total absence of rental market. Nowadays, many of these families are still paying their houses, some of already with reparation needs but without money to do the necessary repairs. Data from Census revealed that $29 \%$ of the Portuguese housing needs some kind of reparation (Figure 6).

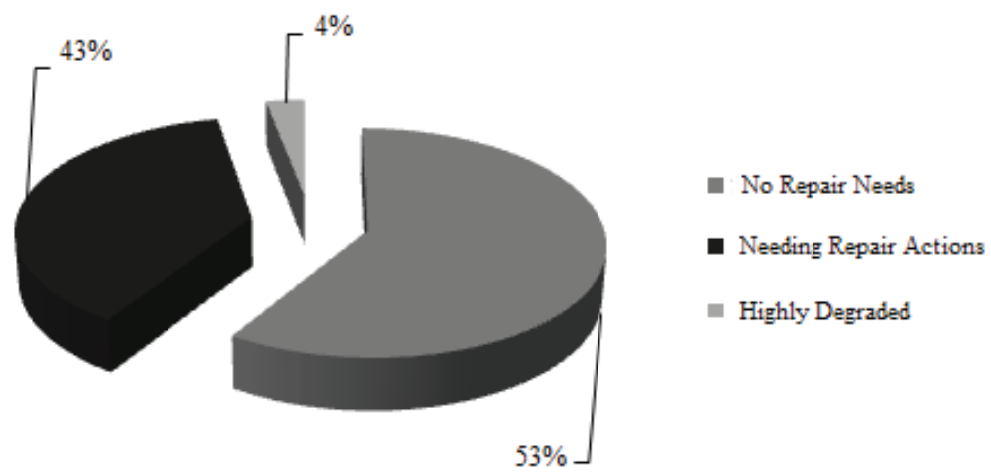

Fig. 6. Percentage of Reparation Need in the Portuguese Building Stock 
The majority of repair works that are needed on buildings should focus on exterior walls and window frames (approximately 1.256.094 buildings with reparation needs). However, there was also a significant number of repair works in coverage and in the structure, with respectively, 1.169 .591 and 1.087 .849 buildings needing some kind of repair (Figure 7).

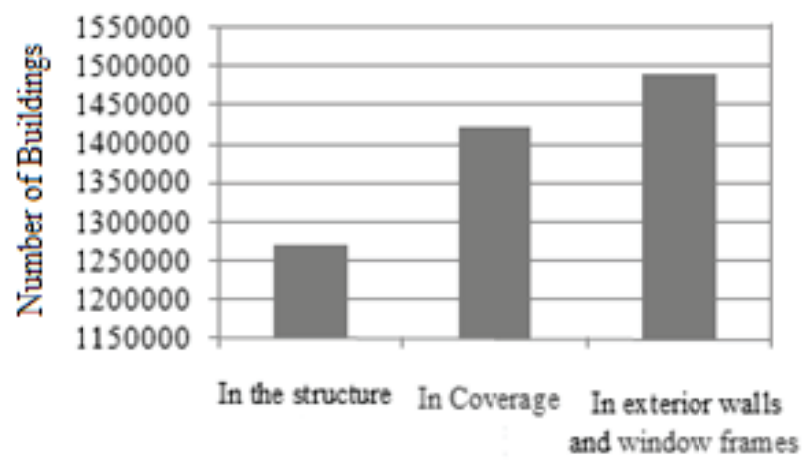

Fig. 7. Needs of Repair in Portuguese Buildings by Part of the Structure

The current economic and financial crisis in the country changed the dynamic on the housing rental market due to the increasing number of families looking to rent a house rather than buying one in a country with strong tradition of homeownership like the majority of South European Countries (Figure 8). According with data from Portuguese Statically Institute, the number of houses available to rent increased $37,6 \%$ and the rented housing stock grew 6,3\% since 2001 [30].

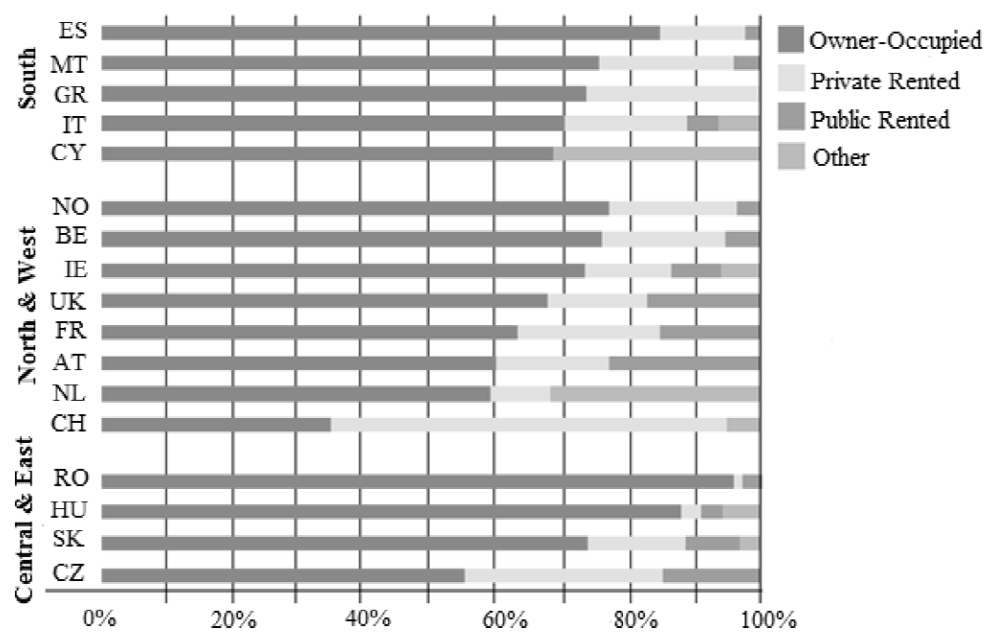

Fig. 8. Tenure of Residential Buildings in Europe 
The type of owner of the buildings has direct influence on its possibilities/chances to be rehabilitated. In Europe the majority of the residential building stock is private ownership (half of residential buildings are occupied by the owner) while $20 \%$ corresponds to social housing which is mainly handled by public ownership. However, there are some exceptions like the Netherlands where social housing is fully owned by privates and countries like Austria, Czech Republic, Ireland and France, where there is an increasing trend towards private involvement.

This can be a unique opportunity to correct the past mistakes. The rehabilitation appears as an opportunity to upgrade the existing building stock, increasing their energy efficiency, comfort conditions and market value.

The rehabilitation, particularly the energy rehabilitation of the Portuguese residential buildings, should contribute to solve residential buildings problems, as well as the social ones, and also the energy dependency of the country. The rehabilitation should bring back to the market, unoccupied or energetically inefficient buildings, increasing also its real estate value. In response to social needs, the investment on rehabilitation would contribute to increase the life quality of the residents and to create new job opportunities. The reduction of the energy consumptions, that might be achieved, would be economically advantageous, both for the residents and the country and would also ensure the intergenerational sustainability of building stock.

Despite the positive effects for the society, the rehabilitation in general and the energy rehabilitation of buildings in particular have not a significant role in the Portuguese construction market. The absence of a wide spread awareness about the subject is perhaps one of the most important difficulties to its promotion.

\subsection{Portuguese Energy Consumption Characterization vs Europe}

\subsubsection{Evolution of Energy Consumes}

Portugal is a country without relevant fossil energy resources exploration. Thus, the main way of supplying the country with energy sources necessary to run the economy is through the importation of petrol and natural gas from other countries which has been increasing in the last decade [31]. This situation places the country in a fragile economical situation every time that an oil crisis comes up.

The household sector is the third sector with biggest consumption of energy resources. At this sector, the consumption of electricity has been growing by the years due to the new consumption habits of the population. This sector depends mainly on electrical energy, which is produced mainly through dams, thermal centrals and renewable sources like wind energy. The mentioned economical sectors represent the biggest consumers of energy as it is possible to see in Figure 9. 


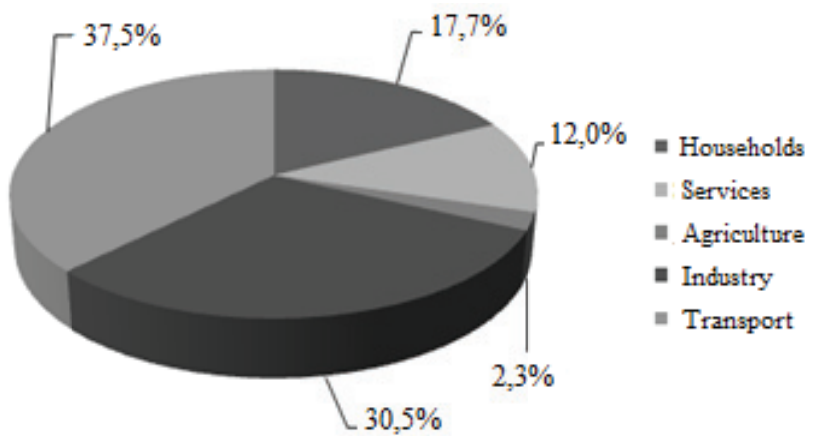

Fig. 9. Percentage of Final Energy Consumption by Economical Activity in Portugal

In Europe, the sum of energy consumption in the Residential Buildings $(27 \%$ of all the European final energy consumption) and Services Buildings (13\% of all the European final energy consumption) consumes about $40 \%$ of total final energy requirements and more than the transport sector, with an energy consume of $33 \%$ (Figure 10). In Portugal, the consumption of buildings represents about $30 \%$ of the final energy consumption (17,7\% of households and $12 \%$ of services energy consumption) of the country which means that, there is a real possibility of an increase in buildings energy consumption over the next few years.

In the last decades, a profound changing on Portuguese family's energy consumption habits has been happening. With the increase in purchasing power and the improvement of living conditions, people become fit to have better comfort conditions which increased significantly the energy consumption in residential buildings.

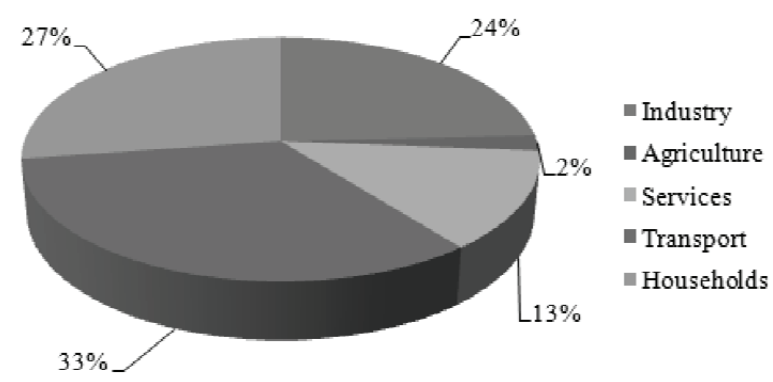

Fig. 10. Percentage of Final Energy Consumption by Economical Activity in Europe

Currently, in the Portuguese households, the main used energy source is electricity, representing $42,6 \%$ of the total energy consumption, followed by the firewood that arises as the second main energy source, with $24,2 \%$ of the energy consumed (Figure 11). 


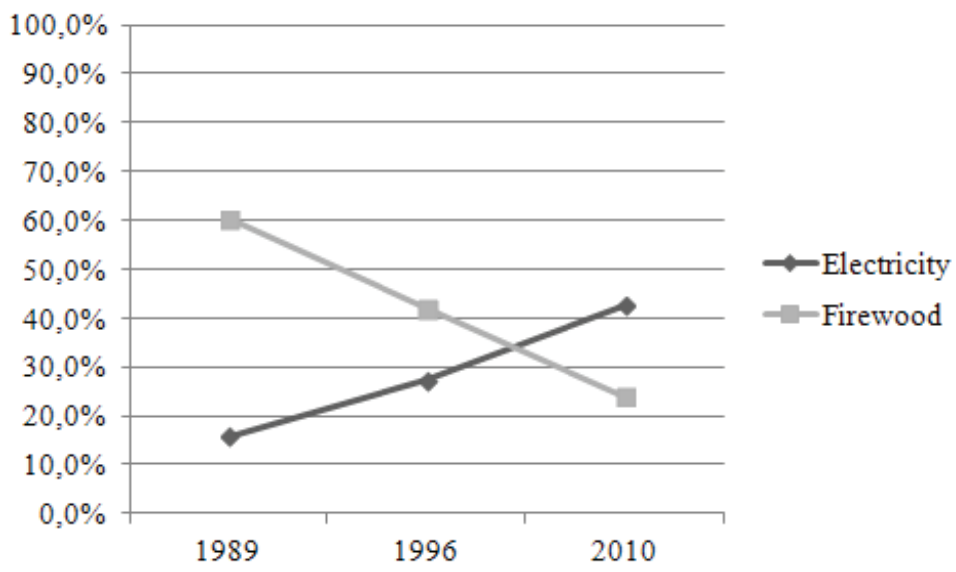

Fig. 11. The Evolution on Electricity and Firewood Consumptions

The continuous growing of electricity consumption in Portuguese residential buildings, which leads to a major role of this energy source in the domestic sector, is directly related with the increasing use of equipments using this type of energy but also with an increase in thermal comfort. This can explain why electricity registered the greatest consumption evolution when compared with all other energy sources. In 1989, the electricity consumption represented $15,8 \%$ of the total energy consumption and in 1996 about $41,9 \%$ of the total energy consumption, in households. In 2010, the consumptions of electricity corresponded to an average consume of 0,316 toe for household.

Other explanation to the increase in electricity consumption is that in the majority of the Portuguese usual residential lodging there are no central heating devices (about $75 \%$ ). In this case the equipments used for heating are open fireplaces, heat stoves, portable and fixed heating devices (Figure 12). About 14\% of the usual residential lodging does not own any kind of heating device [25].

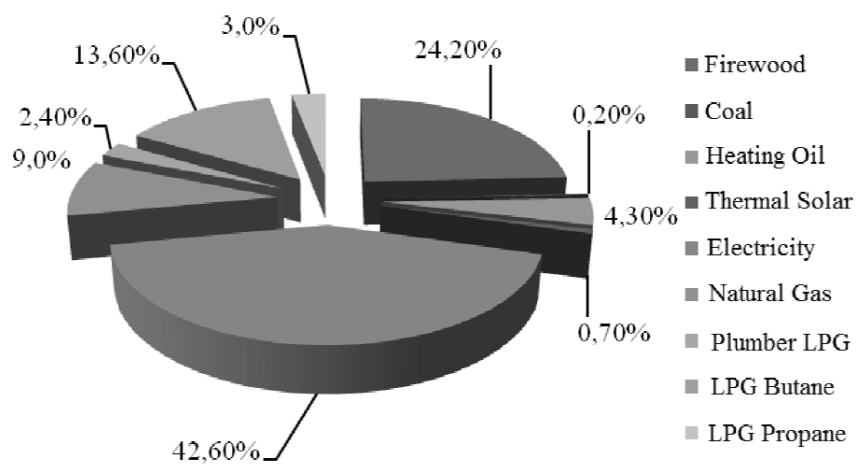

Fig. 12. Energy Consumption in Households According with the Source of Energy in Portugal 
Comparatively to the energy consumption in households in Europe (independently if it is North \& West, Central \& East and South Europe), Portugal has a much higher electricity consumption $(42,60 \%)$.

The sources of energy used in the South of Europe coincide with the major energy sources used in Portugal. Nevertheless, the implantation rate of renewable energy sources (RES) is not very significant in this region besides the good geographical situation to explore some of the like, i.e. the solar energy when compared with the majority of the European countries.

In Central and East Europe the Coal (41\%) and the District Heat (29\%) represent two of the major energy sources while in North and West Europe, Gas (39\%), Biomass (21\%) and RES, Domestic Heat (DH) and Liquefied Petroleum Gas (LPG) (21\%) represent the main sources of energy. It is to note that, in general, the South region of Europe is more dependent on oil (32\%) than Central \& East Europe (3\%) and North $\&$ West $(20 \%)$ is still a region without oil resources (Figure 13).
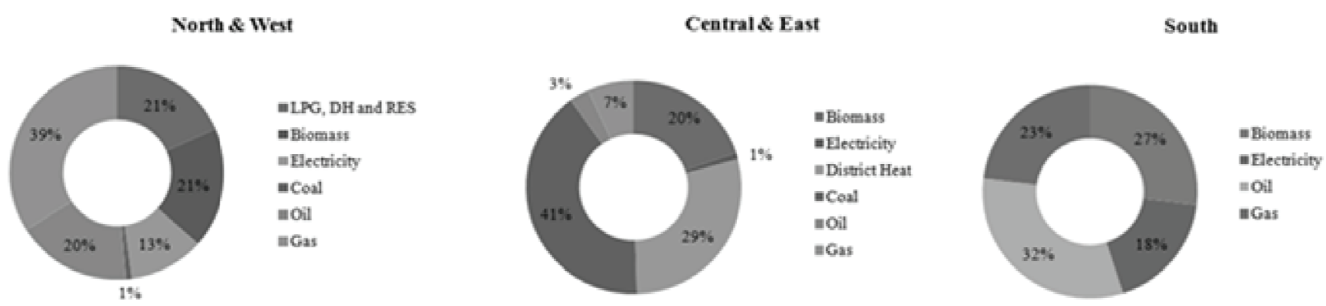

Fig. 13. Energy Consumption in Households According with the Source of Energy in Europe

Since these countries have no fossil energy resources, the importation of energy resources is significant, mainly in oil case, which is one of the most expensive energy sources. This fact is not only harmful for the economy of these countries but also for the environmental sustainability.

\subsubsection{Evolution of Energy Consumes}

Considering the different uses of energy in households, energy used in the kitchen has the highest weight, accounting for over one third (39\%), compared to other types of use, followed by water heating with $23 \%$ (Figure 14).

However, depending on the type of use, the dominant source of energy is different: in the kitchen dominates the use of electricity, while in water heating is predominant the use of bottled LPG (Liquefied Petroleum Gas).

Considering the final use of electricity, it becomes clear that consumptions in the kitchen and in electrical appliances were the highest, being responsible for, respectively, $41 \%$ and $33 \%$ of the overall electricity consumption in the reference period.

The energy used for heating and cooling of indoor spaces is accounted for nearly one quarter $(22 \%)$ of total energy consumption of housing in 2010. 


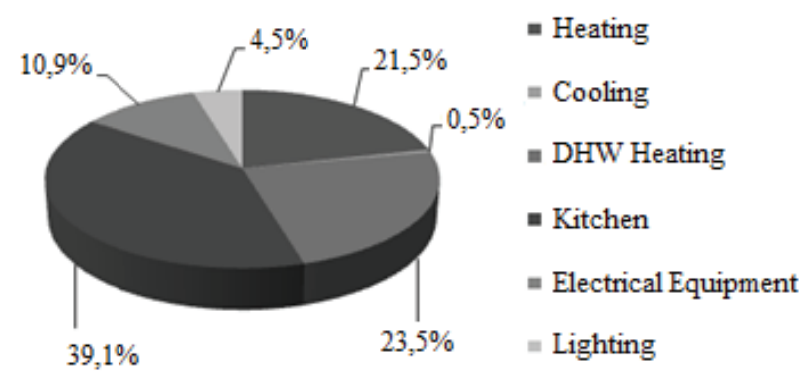

Fig. 14. Percentage of Energy Font in Household According with the kind of Use

\subsection{The Evolution of the Structural Elements in Portugal}

\subsubsection{Evolution of Buildings Facades}

The construction technology of the structural elements in Portugal has been changing with time. Since 1940, particularly in large urban centres, there was a further development of building technology with the generalization of reinforced concrete structures on the decks, which later were applied on the vertical resistant elements, including the façade walls. Nevertheless at that time the thick and heavy masonry stone walls were the prevalent façades of the Portuguese buildings.

It was only around the 1950's that the first double walls started to emerge in Portugal. The first double walls consisted of a cloth stone masonry and cloth brick masonry interspersed with an air box. At this time it wasn't used any insulation because it was believed that the air-box alone was enough to ensure good insulation and create comfort conditions inside the home.

The stone heavy façade walls gave way to lighter construction materials, including clay bricks. After 1960, the exterior walls in Portugal become constituted by two panels of brickwork, with the interposition of an air-box. The generalization of the double wall ceramic materials façades allowed essentially lightening the weight of the walls. The application of this construction technology continued in the 70's and in the 80's.

Despite the first thermal behaviour characteristics in dwellings came into force in 1991, the façades insulations were introduced in the 70's, after the first major global oil crisis which demonstrated the high energy dependence of developed countries. But it was only after the entry into force the first regulation of thermal behaviour characteristics in dwellings, that the use of thermal insulation in Portuguese building's façade became widespread in Portuguese construction.

The first regulation for thermal comfort in buildings was approved in 1990 by the Decree-Law n. ${ }^{\circ} 40 / 90$ of 6th February and it is known as Regulation of the Characteristics of Thermal Performance of Buildings (RCCTE) which came into force in 1991 [32]. 
Portugal was the last European country to impose a regulation on this matter, adopting the experience in other European countries with identical climate conditions. However, at some points the RCCTE was an innovative regulation which has in account some aspects like the comfort in summer, the requirements on sunscreen glazing and the reduction for heating and cooling needs in new buildings. The RCCTE established rules that include not only the new buildings but also all the major renovations in order to improve the interior thermal comfort of the places. These should be comfortable but without spending an exaggerated consumption of energy. In the end of the 80's there were few buildings with HVAC (heating, ventilation, and air conditioning) systems. Currently there is a wide dissemination of the same and a growing increase in the use of air conditioning equipment in the housing sector. The growing use of air conditioning systems but also the need to implement the European Directive 2002/91/CE on the energy performance of buildings called for a new regulatory framework in $2006[33,34]$.

The new version of RCCTE forced the installation of solar panels to produce hot water, which paved the way for the expansion of renewable solar energy market, contributing to the reduction of two factors: the emission of greenhouse gases and the importation of energy.

In the 80's and 90's there was a significant increase in housing demand in Portugal. The lack of qualification of labour, the introduction of some construction technologies without proper knowledge of designers and the undemanding regulation were some of the factors that led to a housing stock without quality.

In Figure 15, it is possible to see an approximation of what was the evolution of the walls in Portugal in recent decades.

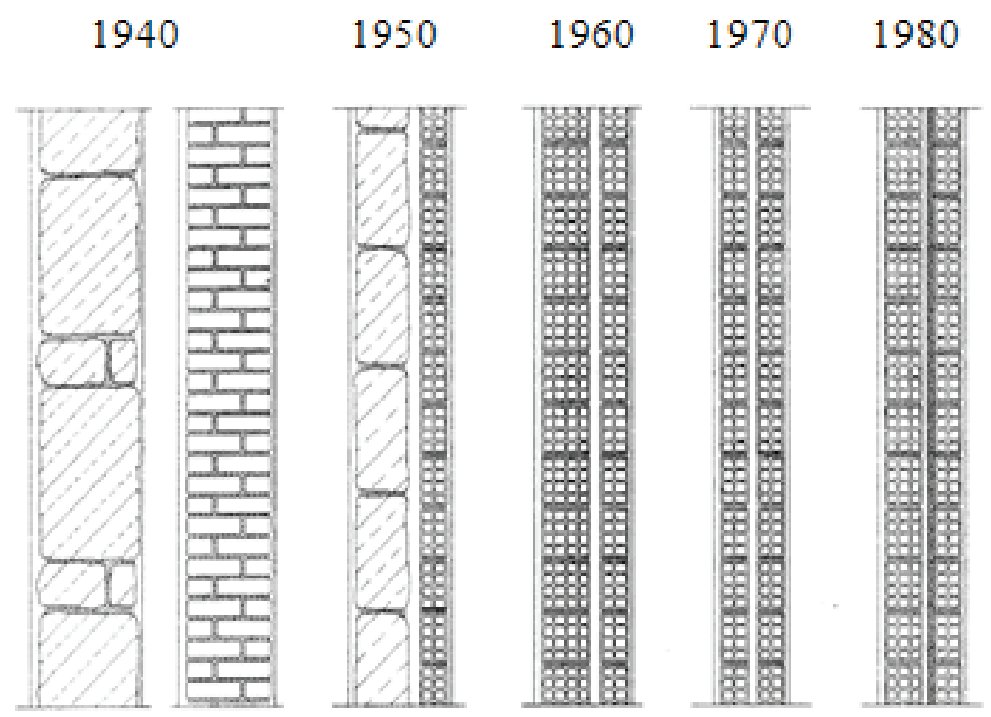

Fig. 15. Evolution of Façades in Portugal from 1940 to 1980 decades [34] 


\subsubsection{Roofs Constructive Techniques Evolution}

The evolution of construction technique was felt in other structural elements like the roofs. At first the traditional roofs were done with tiles supported by basic and primary structures of wood. Subsequently, the coating of roofing happened to be seated in a wooden lining. Although at the time thermal insulation materials were not applied in roofs, another variant technique was developed and used in order to attempt to retain the heat from fireplaces inside homes. Instead of using wooden lining, reeds were interlaced and attached to the beams over which was placed a layer of mortar and then applied the ceramic material (tiles). Depending on the region coatings stone ware also used, thatch and slate replaced ceramic material since it had effective protection to temperature oscillations [36].

In the 1940's, coverings of buildings were essentially inclined, coated with ceramic elements and structurally supported by beams, and wood trusses, as shown in Figure 16.

With the advancing on constructive technologies flat roofs started to be used (with particular focus in the south of Portugal) constituted by bricks that formed cap vaults or by application of tiles in two or three layers with mortar seated in wooden beans.

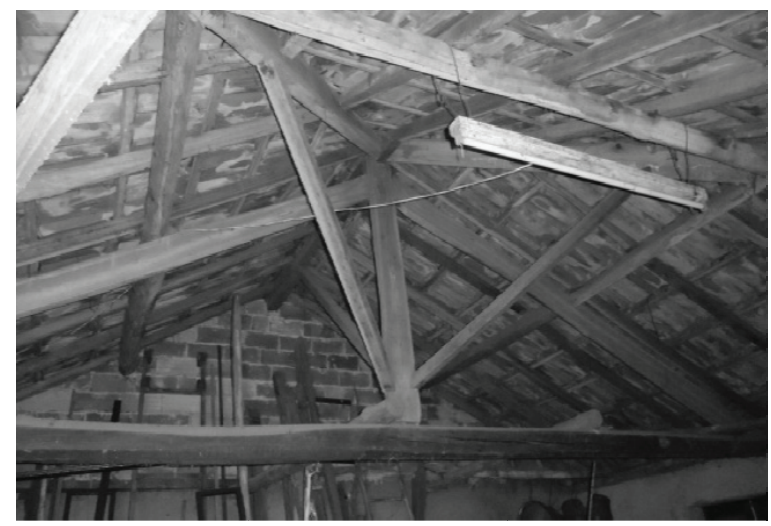

Fig. 16. Covering Structurally Supported by Wood Trusses

In the north of the country the pitched roofs continued to be the most prevalent image, due to the very different climatic characteristics between these regions. However, whether in the north or in the south of the country there use of thermal insulation application in the roof was not used.

In 1980 and 1990, there was an evolution of initially ventilated spaces of covers for unventilated spaces. The coatings of pitched roofs remained mostly using ceramics materials but the structural elements initially of wood were replaced by concrete ones.

One of the great advantages of concrete was the versatility in the manufacturing method. The components of the roofs could be prefabricated like joists or it could be either manufactured in situ by concreting solid slabs Figure 17. 


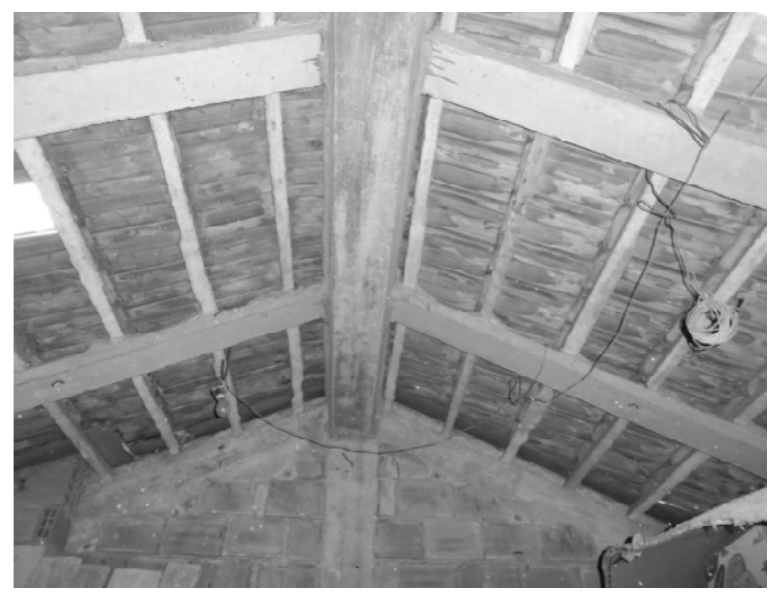

Fig. 17. Covering Structurally Supported by Prefabricated Beams

In these decades there was a proliferation of flat roofs, nowadays these type of roofs are no longer concentrated in the south, but distributed throughout the country. It was at this time that thermal insulation materials started to be introduced in the roofs components independently if they were inclined or flat.

\subsubsection{Pavements Constructive Techniques Evolution}

Initially the pavements of dwellings with more than one floor were mostly wooden floor with a roof lining. These pavements were supported by wooden beams whose dimensions varied according with the compartments dimensions. This type of flooring has particular importance between 1750 and 1930 [37]. The type of woods generally employed in the wood floors was pine and cone, which were used on long tables arranged in the same direction that were nailed to wooden beams. Wooden floors were gradually replaced by floors containing ceramic elements. These slabs consist on prefabricated prestressed beams and lightened ceramic elements which is a constructive technique frequently used in the north of the country. Since 1960 with the generalization of building construction in height using reinforced concrete, the use of tunnel formwork became more frequent. The tunnel formwork system consisted of a metal formwork allowing concreting simultaneously exterior walls, interior and slabs [38]. Usually consisted of two half tunnels or tunnel complete with lengths of around 2 meters. The tunnel formwork walls and reinforced concrete slabs had particular expansion in the early 90's and were mainly applied in social housing construction. However, despite this type of implementation show good characteristics in respect to the functionality and leak requirements in relation to acoustic and thermal insulation behaviour they provided a poor quality of life for its inhabitants. Like in the other structural elements the application of thermal isolation in slabs in contact with the 
exterior or non heated spaces was only a common practice after the implementation of the first RCCTE.

\subsection{Evaluation of U-Values According with some Periods of Construction}

As mentioned before, there is a high probability to achieve, in older buildings, higher heat transfer coefficients (U-values) in the structural elements (such as façades, roof and pavements) due to the fact that construction was made during a period without stringent thermal regulations.

The heat transfer coefficients of the buildings' structural elements have been characterized, according with four periods of construction. These periods were based on time intervals defined in the Database of Experts from the Portuguese Agency for Energy (ADENE), including the following periods of time [39]:

- Before 1950;

- From 1951 to 1970;

- From 1971 to 1990;

- From 1991 to 2006;

- From 2006 to 2011.

The results were obtained based on a weighted average of the values of Energy Certifications after a Statement of Regulatory Compliance (DCR), and the obtained values in the energy certification that did not need a Statement of Regulatory Compliance (DCR), i.e., existing buildings (Figure 18). The Energy Certifications after DCR imply that energy certificates prior to construction of the building have been executed.

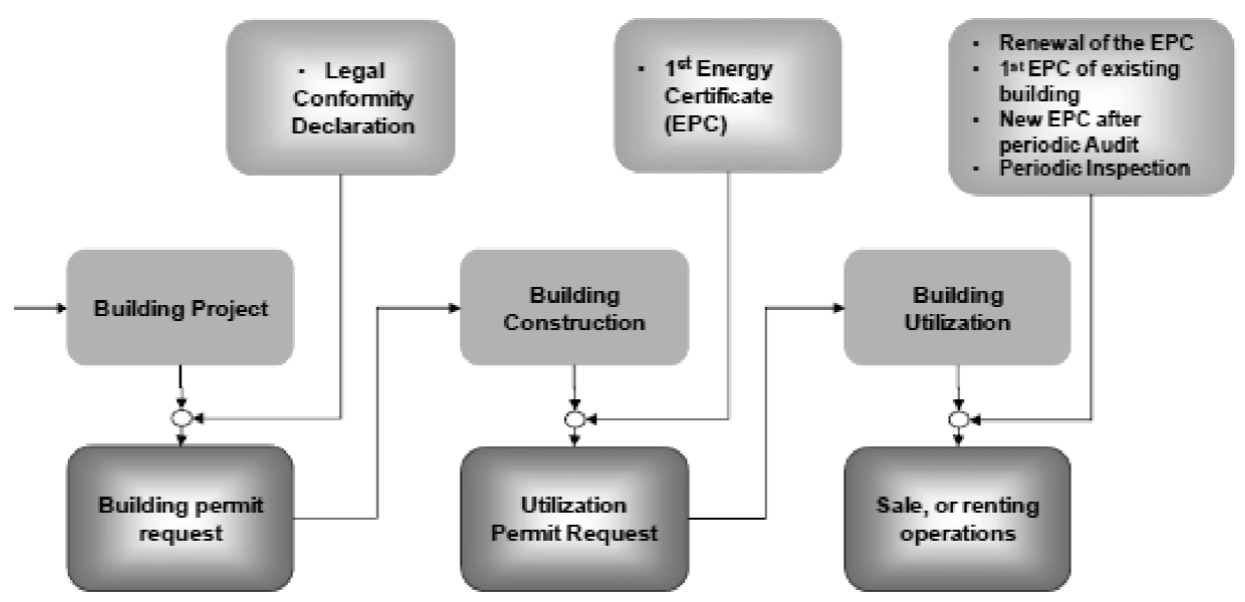

Fig. 18. Summary of Qualified Experts Work 
2.5.1. Average U-values of Façades for Period of Construction in Portugal

According with the existing information in the ADENE expert's database, there is a difference between fractions and dwellings, so the heat transfer coefficients were analysed for both types of housing.

It was found that the average values of the U-values remained constant, regardless the housing it is a fraction or a dwelling. In general, it is possible to observe that U-values of the exterior walls of the housing have been declined over the decades (Figure 19) mainly due to the introduction of new constructive technologies and the appliance of thermal insulation.

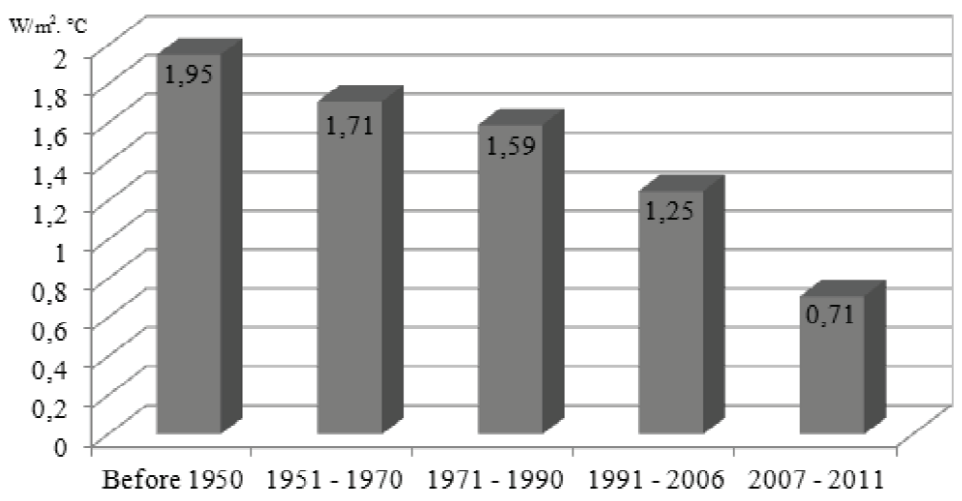

Fig. 19. Characterization of the U-values in Exterior Walls for decade of Construction

Even after the implementation of the first thermal regulation, RCCTE (which came into force in 1991), was continued to verify that the constructive solutions adopted in building facades do not correspond to energy-efficient solutions. In general it was found that the mean U-values are unacceptably high, despite the decade of construction to be concerned on fractions or dwellings (Table 1).

Table 1

Maximum U-values for Façades According with RCCTE

\begin{tabular}{|c|c|}
\hline Climate Zone & Maximum U-Value \\
\hline I1 & $1,80 \mathrm{~W} / \mathrm{m}^{2} .{ }^{\circ} \mathrm{C}$ \\
\hline I2 & $1,60 \mathrm{~W} / \mathrm{m}^{2} .{ }^{\circ} \mathrm{C}$ \\
\hline I3 & $1,45 \mathrm{~W} / \mathrm{m}^{2} .{ }^{\circ} \mathrm{C}$ \\
\hline
\end{tabular}

Despite the decrease of U-values in exterior walls over time these are generally too high for the maximum U-values currently practiced. An example is the U- value of exterior walls in buildings built before 1950, which does not respect the maximum 
U-value for any climate zone imposed by the current RCCTE for exterior opaque vertical elements.

The thermal coefficients for the facades of buildings constructed in the period 1951 to 1970 and from 1971 to 1990 , may comply with the current values depending on the climate zone where the building is located.

\subsubsection{Average U-values of Roofs for period of Construction}

Through the evaluation of the average U-values of roofs of the Portuguese buildings it was found that like the average U-values of facades remained constant, regardless been a fraction or a dwelling housing.

As happened with the U-values of facades, the average U-values of the roofs of the housing have been declined over the decades (Figure 20), with no surprise due to some of the already explained reasons like the introduction of thermal insulation.

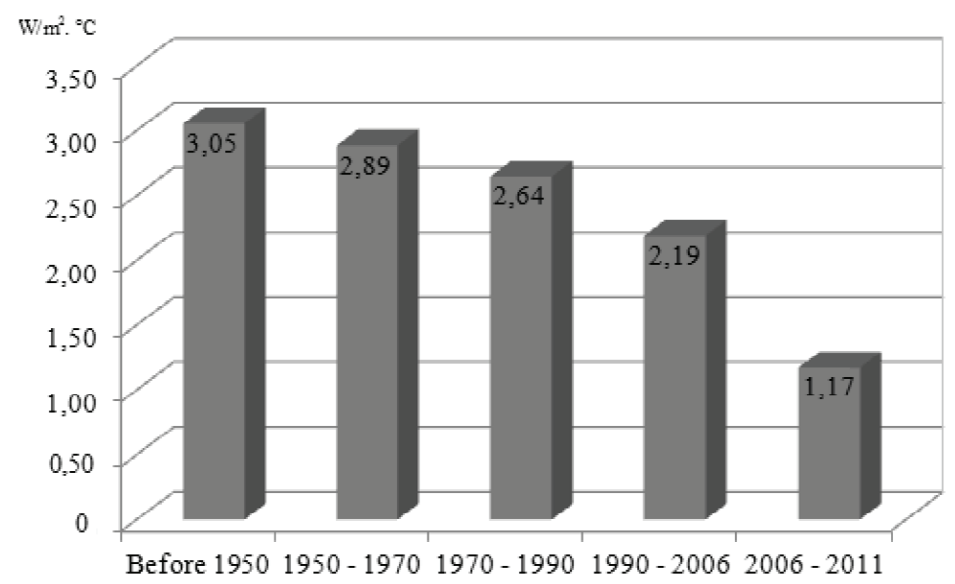

Fig. 20. Characterization of the U-values of Roofs for decade of Construction

Table 2

Maximum U-values for Roofs According with RCCTE

\begin{tabular}{|c|c|}
\hline Climate Zone & Maximum U-Value \\
\hline I1 & $1,25 \mathrm{~W} / \mathrm{m}^{2} \cdot{ }^{\circ} \mathrm{C}$ \\
\hline I2 & $1,0 \mathrm{~W} / \mathrm{m}^{2} \cdot{ }^{\circ} \mathrm{C}$ \\
\hline I3 & $0,90 \mathrm{~W} / \mathrm{m}^{2} .{ }^{\circ} \mathrm{C}$ \\
\hline
\end{tabular}

In a general way, the average U-values for decade in roofs are also too high for the maximum U-values currently practiced. As it is possible to see in Table 2, until the year 
2006 none of the average U-values obtained respected the maximum values defined in the current legislation (Table 2). If we consider the climate zone I3, which is the less exigent, not even this last period is according with the actual legislation.

\subsubsection{Average U-values of Pavements for period of Construction}

The evaluation of U-values of pavements in contact with exterior zones revealed that the average U-values are in line with the previous results so they are too high, even that after 2006 it has been a significant decrease.

Through the evaluation of Figure 21 it is possible to see that any of the average U-Values obtained in pavements respect the maximum values established by RCCTE, which are the same values of roofs mentioned in Table 2.

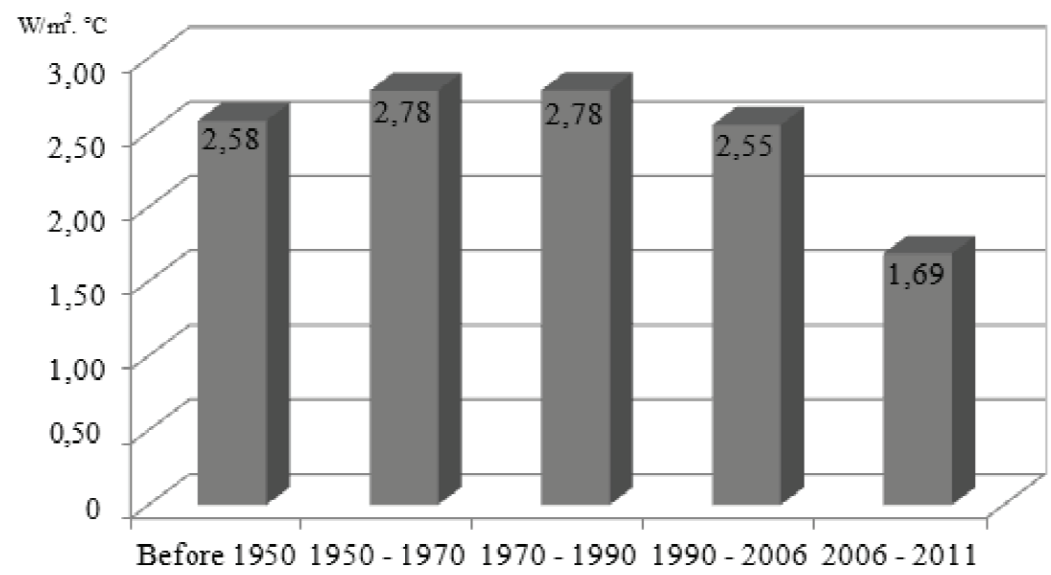

Fig. 21. Characterization of the U-values of Pavements for decade of Construction

\section{Conclusions}

It is known that older buildings have a higher probability of consuming more energy than recent ones. It is also already known that older buildings have the tendency to have higher U-values than more recent ones that were already built according to the thermal regulations and by more accurate construction techniques. Despite legislation introduced and the progress made, it was found that there is still much to be done in order to attain a quality level of thermal comfort of dwellings associated with a lower electricity bill.

Comparing the Portuguese building stock with other European countries, some of the most recent buildings already need urgent repairs mainly in respect to façade elements. It is not a revelation that the average U-values of parts of the structures 
of buildings decrease in most recent ones. The biggest revelation is that the average U-Values for any part of building are extremely high and, even in the most recent period, in some cases the actual legislation is not fulfilled.

The obtained values represent average values, as mentioned before, and pretend to give a general idea of the current situation. The energetic rehabilitation of the Portuguese stock could be an extreme advantageous measure for the economy, for the society and even for the environment, concluding that it could bring to market these buildings and, simultaneously, could help to reduce the importation of energetic resources.

\section{REFERENCES}

1. B. Breemhaar, W. van Gool, P. Ester, C. Midden. Life styles and domestic energy consumption: a pilot study. Climate Change Research: Evaluation and Policy Implication. S. Zwerver, R.S.A.R. van Rompaey, M.T.J. Kok and M.M. Berk. 1995. pp. 1235-1240.

2. D. Heim, The simultaneous effect of the operating temperature and solar radiation on the efficiency of photovoltaic panels, Archives of Civil Engineering, v. 57, iss. 3(2011), 261-274.

3. D. Brounen, N. Kok, J. M. Quigley. Residential energy use and conservation: Economics and demographics. European Economic Review. July 2011.

4. P. Silva, M. Almeida, L. Bragança, V. Mesquita. Performance evaluation of non-conventional constructions: Case study in a temperate climate. Applied Thermal Engineering 42 (2012) 136-144.

5. G. Habert, E. Castillo, E. Vincens, J.C. Morel. Power: A new paradigm for energy use in sustainable construction. Ecological Indicators 23 (2012) 109-115.

6. European Directive 2010/31/EU of the European Parliament and the Council of 19 May 2010 on the energy performance of buildings (recast). Official Journal of the European Communities n. ${ }^{\circ}$ L 153, of June 18, 2010. pp. 1-26. European Union: Brussels.

7. J. Ferreira, M. Pinheiro. In search of better energy performance in the Portuguese buildings - the case of the Portuguese regulation. Energy Policy 39 (2011) 7666-7683.

8. J. A. Reis, P. Escórcio. Energy certification in St. António (Funchal) - Statistical analysis. Energy and Buildings 49 (2012) 126-131.8.

9. E. Asadi, M. G. Silva, C. H. Antunes, L. Dias. Multi-objective optimization for building retrofit strategies: A model and an application. Energy and Buildings 44 (2012) 81-87.

10. C. Petersdorff, et al., Mitigation of $\mathrm{CO} 2$ emissions from building stock, in: Beyond the EU Directive on the Energy Performance of Buildings, Ecofys, Cologne, Germany, 2004 (DM 797).

11. H. Tommerup, S. Svendsen. Energy savings in Danish residential building stock. Energy and Buildings 38 (2006) 618-626.

12. I. Ayers, S. Raseman, A. Shih, 2009. Evidence from two large field experiments that peer comparison feedback can reduce residential energy usage. NBER Working Paper 15386.

13. L. Georges, C.Massart, G.Van Moeseke, A. De Herde. Environmental and economic performance of heating systems for energy-efficient dwellings: Case of passive and low-energy single-family houses. Energy Policy 40 (2012) 452-464.

14. Inquérito ao Consumo de Energia no sector doméstico 2010. (Survey on Energy Consumption, in Portuguese). 2011. National Institute of Statistics and General Directorate for Energy and Geology: Lisbon.

15. R. Huisman, M. Kiliç. A history of European electricity day-ahead prices. Applied Economics, 45:18, 2683-2693. 
16. C. A. Balaras, A. G. Gaglia, E. Georgopoulou, S. Mirasgedis, Y. Sarafidis, D. P. Lalas. European residential buildings and empirical assessment of the Hellenic building stock, energy consumption, emissions and potential energy savings. Building and Environment 42 (2007) 1298-1314.

17. C. A. Balaras, K. Droutsa, E. Dascalaki, S. Kontoyiannidis. Heating energy consumption and resulting environmental impact of European apartment buildings. Energy and Buildings 37 (2005) 429-442.

18. F. Uмвасн. Global energy security and the implications for the EU. Energy Policy, 38 (2010), pp. 12291240.

19. J. BIELECKI. Energy security: Is the wolf at the door? The Quarterly Review of Economics and Finance, 42 (2002), pp. 235-250.

20. UNFCCC, 2010. Kyoto Protocol. United Nations Framework Convention on Climate Change. http:// unfccc.int/kyoto_protocol/items/2830.php, website consulted $4^{\text {th }}$ December 2012.

21. Eurostat, 2009. Panorama of Energy. Statistical Office of the European Communities.

22. Eurostat, 2009. Energy, transport and environment indicators. Statistical Office of the European Communities.

23. D. Wiesmann, I. L. Azevedo, P. Ferrão, J. E. Fernández. Residential electricity consumption in Portugal: Findings from top-down and bottom-up models. Energy Policy, 39 (2011), pp. 2772-2779.

24. Presidência do Conselho de Ministros, 2010. Resolução do Conselho de Ministros N. ${ }^{\circ}$ 29/2010, Diário da República 1.a série N. ${ }^{\circ} 73$.

25. R.J. Brecha, A.Mitchell, K.Hallinan, K.Kissock. Prioritizing investment in residential energy efficiency and renewable energy - A case study for the U.S. Midwest. Energy Policy 39 (2011) 29822992.

26. Censos 2011: resultados definitivos - XV recenseamento geral da população - V recenseamento geral da habitação. (Census 2011 final results, in Portuguese). 2012. National Institute of Statistics: Lisbon. http://censos.ine.pt/xportal/xmain?xpid=CENSOS\&xpgid=censos2011_apresentacao, website consulted on $4^{\text {th }}$ December 2012.

27. Statistics Portugal - Number of Buildings, Lodging and Classic Family Lodging in Portugal (2011) http://www.ine.pt/xportal/xmain?xpid=INE\&xpgid=ine_princindic, website consulted on $9^{\text {th }}$ June 2012.

28. Statistics Portugal - Average age of Buildings (2001) http://www.ine.pt/xportal/xmain?xpid= INE\&xpgid=ine_indicadores\&indOcorrCod $=0000969 \&$ contexto $=$ bd\&selTab=tab2, website consulted on $9^{\text {th }}$ June 2012.

29. Europe's Buildings under the Microscope. A country-by-country review of the energy performance of Buildings. October 2001. Buildings performance Institute of Europe (BPIE).

30. Censos 2011 - Resultados Provisórios. (Provisional Results, in Portuguese). December 2011. National Institute of Statistics: Lisbon.

31. A Factura Energética Portuguesa 2010 (The Portuguese Energy Bill). May 2011. General Directorate for Energy and Geology, Ministry of Economy Innovation and Development: Lisbon.

32. Regulamento das Características de Comportamento Térmico dos Edifícios (RCCTE), (Thermal Buildings Regulation, in Portuguese). Decree-Law n. ${ }^{\circ} 40 / 90$ of $6^{\text {th }}$ February 1990.

33. European Directive 2002/91/CE of the European Parliament and the Council of 16 December 2002 on the energy performance of buildings. Official Journal of the European Communities n. ${ }^{\circ} \mathrm{L} 1$ of January 4, 2003, pp. 65-71. European Union: Brussels.

34. Regulamento das Características de Comportamento Térmico dos Edifícios (RCCTE), (Thermal Buildings Regulation, in Portuguese). Decree-Law n. ${ }^{\circ}$ 80/06, of April 4, 2006.

35. H. Sousa, Melhoria do Comportamento Térmico e Mecânico das Alvenarias por Actuação na Geometria dos Elementos - Aplicação a Blocos de Betão de Argila Expandida. Thesis submitted to Faculty of Engineering, University of Porto for a PhD in Civil Engineering. Porto, FEUP, 1996. 
36. V. Abrantes, "O Comportamento térmico de coberturas típicas Portuguesas" (Thermal Behaviour of Portuguese Typical Coverage). Revista Arquitectura n. ${ }^{\circ}$ 140. Lisboa, Março 1981.

37. C. Santos, R. Rodrigues. "Coeficientes de Transmissão Térmica de Elementos Opacos da Envolvente dos Edifícios - Soluções construtivas de edifícios antigos e das regiões autónomas." LNEC, Lisboa, 2009.

38. V. C. Silva. "Cofragem túnel; Aspectos práticos sobre um caso concreto". Paredes de Edificios CPP 510. Lisboa 2003.

39. Database of Qualified Experts from the Portuguese Agency for Energy (ADENE).

40. Implementing the Energy Performance of Buildings Directive (EPBD). Featuring Country Reports 2010. April 2011. Brussels.

41. N. Kohler, P.Steadman \& U. Hassler (2009): Research on the Building Stock and its applications. Building Research \& Information, 37:5-6, 449-454. 